\title{
Determinants Analysis of Satisfaction with Supporting System for Hearing Aids
}

\author{
Jung Hyun Chang ${ }^{1}$, Chang Eui Hong ${ }^{1}$, Jun Cheol Park ${ }^{1}$, Jung Kyu Choi ${ }^{2}$, and Hyun Seung Choi ${ }^{1}$ \\ ${ }^{1}$ Departments of Otolaryngology-Head and Neck Surgery, ${ }^{2}$ Policy Research Affairs, National Health Insurance Service Ilsan Hospital, \\ Goyang, Korea
}

보청기 지원체계에 대한 인식에 영향을 미치는 요인 분석

장정현 ${ }^{1} \cdot$ 홍창의 $^{1} \cdot$ 박준철 $^{1} \cdot$ 최정규 $^{2} \cdot$ 최현승 $^{1}$

국민건강보험 일산병원 이비인후과, ${ }^{1}$ 정책연구부 ${ }^{2}$

Received February 7, 2017

Revised April 20,2017

Accepted April 24, 2017

Address for correspondence

Hyun Seung Choi, MD

Department of Otolaryngology-

Head and Neck Surgery,

National Health Insurance Service

Ilsan Hospital,

100 Ilsan-ro,

Ilsandong-gu, Goyang 10444, Korea

Tel $+82-31-900-0972$

Fax $+82-31-900-0343$

E-mail choihyunseung@gmail.com
Background and Objectives Hearing disability has a negative impact on the psychological condition and the quality of life of patients, as well as their daily lives. This study tries to identify the relationship between personal perception of the national supporting system for hearing aids and the satisfaction of the supporting system on the part of users, suppliers and specialists.

Subjects and Method A total of seven questions were developed to identify factors that can affect the satisfaction of national supporting system for hearing aids. We surveyed hearing aids users, suppliers, and specialist; the final sample included 455 subjects.

Results Determinants of satisfaction were adequacy of accepted durability of hearing aids, accessibility to relevant information, necessity of graded financial support by type of hearing aids, necessity of supporting repair cost and necessity of graded financial support by kind of disability rating. According to the results of multiple logistic regression analysis, subjects who answered that accepted durability of hearing aids [odd ratio (OR): 2.03 , confidence interval (CI): 1.14-3.60] and accessibility to information (OR: 4.82, CI: 2.65-8.78) were proper showed tendency to be satisfied with support system for hearing aids. The subjects who answered that graded financial support by kind of hearing aids (OR: 1.98, CI: 1.10-3.59) and graded financial support by kind of disability rating (OR: $1.91 \mathrm{CI}$ : 1.07-3.42) were necessary showed tendency to satisfy with support system for hearing aids.

Conclusion In order to enhance satisfaction in stakeholder perceptions of supporting system for hearing aids, the system needs provide users with better access to relevant information and help in the use and management of the hearing-aid device.

Korean J Otorhinolaryngol-Head Neck Surg 2017;60(8):381-9

Key Words Hearing aids · Hearing impairment · Insurance coverage $\cdot$ Personal satisfaction.
서 론

청각장애는 우리나라에서 지체 장애, 뇌병변 장애에 이어 3번째로 많은 장애유형으로 약 27만 명 정도로 알려져 있다.

This is an Open Access article distributed under the terms of the Creative Commons Attribution Non-Commercial License (http://creativecommons.org/licenses/by-nc/4.0) which permits unrestricted non-commercial use, distribution, and reproduction in any medium, provided the original work is properly cited.
중복 장애를 감안하여 추산한 청각장애인은 31만 명 정도 생 각되며 전체 장애인의 $10.5 \%$ 를 차지한다. 한 조사에 의하면 청 각장애인이 가장 많이 사용하는 의사소통 방법은 '말(80.3\%)' 이며, '구화(7.5\%)', '수화(6.0\%)'라고 한다. ${ }^{1)}$ 결과적으로 20만 명 이상의 청각장애인이 말로 의사소통을 하고 있으며, 이들 의 삶의 질 향상과 더 많은 사회적 참여를 위해서는 적절한 보 청기의 사용이 필요하다. 최근 보청기 제작 기술의 발달은 청 
각장애인의 의사소통에 많은 도움을 주었지만 이에 따른 보 청기의 가격 상승은 청각장애인의 경제적 부담이 되고 있 다. ${ }^{2)}$ 국민건강보험에서 제공하는 보청기 급여 금액은 2005년 에 25만 원에서 34만 원으로 일부 조정되었고, 2015년 11월 이후 131만 원으로 대폭 상향되었지만 보청기 구입 지원금액 이외에 보청기의 효과적인 사용을 위한 관리 체계는 전무한 상태이다.

이 연구에서는 보청기 지원체계 현황 및 개선방안에 대한 이 해집단 간의 인식의 차이를 확인하고 보청기 지원체계 만족도 에 영향을 미치는 요인을 파악하며, 보청기 급여 확대에 따른 변화를 확인하고자 하였다.

\section{대상 및 방법}

\section{대 상}

연구대상자는 보청기 이용자, 공급자, 전문가이며, 이들을 대 상으로 보청기 지원체계에 대한 인식도 현황을 설문조사하였 다. 조사기간은 보청기 급여의 기준 금액이 34만 원이었던 2015 년 7월 20일부터 9월 30일까지이며, 설문조사는 보청기 이용 자에게 우편 설문방법을, 공급자 및 전문가에게 이메일 설문 방법을 활용하였다. 보청기 이용자 설문조사는 2014년에 보청 기를 구입하고 지원금을 받은 청각장애인(n=11309) 중에서 거 주지가 불분명한 501명을 제외한 10828명을 모집단으로 설정 하고, 성과 연령, 지역을 기준으로 표본(1000명)을 확률비례 추출하여 설문지를 우편발송하여 진행하였다. 설문조사에 참 여한 공급자는 보청기 영업 및 판매를 담당하는 회사의 직원 을 대상으로 하였고, 전문가는 이비인후과학회 회원 중에서 이과분과에 소속된 정회원을 대상으로 이메일을 발송하여 진 행한 설문 결과를 분석하였다.

\section{설문항목}

저자들은 건강보험제도에 대한 인식 및 만족도 조사와 관 련된 기존의 문헌을 참고하여 보청기 지원체계의 만족도에 영 향을 미치는 요인을 보청기 지원체계 현황에 대한 인식과 지 원체계 개선방안으로 구분하고, 총 7개 문항을 개발하였다. ${ }^{3)}$ 보청기 지원체계 현황에 대한 인식은 3 문항으로, 1) 지원금액 의 적정성, 2) 내구연한의 적정성, 3) 관련 정보의 접근성으로 구성되어 있으며, 지원체계 개선방안은 4문항으로, 4) 청력검 사비용 지원의 필요성, 5) 보청기 종류별 차등지원의 필요성, 6) 장애등급별 차등지원의 필요성, 7) 수리비 지원 서비스의 필요성으로 구성되어 있다. 설문항목에 대해 5점 Likert 척도 로 계량화하였다. 또한 보청기 이해당사자의 보청기 지원체계 에 대한 인식을 확인하고 보청기 지원체계의 보장성 강화를
위해 3가지 항목(대상자 확대, 지원금 확대, 지원서비스 확대) 중에서 최우선으로 시행해야 하는 항목을 조사하였다. 설문 지에 쓰인 용어에 대한 의미가 제대로 전달되는지 확인하기 위해 설문조사를 실시하기 전에 파일럿 테스트를 수행하였 다. 청각장애인의 절반이상이 60 세 이상이었기 때문에 이해 하기 힘든 보험급여, 보장성 등의 용어를 순화하였다. 설문조 사는 Institutional Review Board(IRB) 승인 후에 실시하였다 (승인번호: NHIMC 2015-03-019-001).

\section{통 계}

대상자의 인구사회학적 특성은 빈도분석을 이용하여 확인 하였다. 보청기 이해집단 간의 지원체계에 대한 인식의 차이 를 확인하기 위해 대상자 유형(이용자, 공급자, 전문가)별로 구분하여 교차분석을 실시하였다. 기대빈도 5 미만의 셀이 $20 \%$ 이상 존재하는 경우에 Fisher's exact test를 통해 집단 간의 유의미성을 검증하였다. 독립변수들 간의 다중공선성 을 확인하고 보청기 지원체계의 만족도와 독립변수의 관련성 을 알아보기 위해 Pearson 상관분석을 통해 변수 간 상관관 계를 확인하였다. 독립변수가 보청기 지원체계 만족도에 미치 는 영향의 정도를 파악하기 위해 로지스틱 회귀분석을 적용 하였다. 유의수준은 0.05 를 기준으로 하였으며, 분석에 사용 된 통계 패키지는 SAS 9.1(SAS Inc., Cary, NC, USA)이다.

\section{결 과}

\section{연구대상자의 인구사회학적 특성}

보청기 이용자의 설문지 응답률은 $45.3 \%$ 였다. 남성이 여성보 다 많았으며, 연령이 증가할수록 대상자가 증가하였다. 모집 단과 표본에서 60 대 이상의 비중은 $70 \%$ 이상이었지만 고령 이 용자의 응답률이 떨어져 60 대 이상의 비중은 $60 \%$ 이하로 나 타났다. 설문에 참여한 대상자는 총 548 명이었고, 결측치가 존 재하는 93명을 제외하여 최종분석에 활용된 대상자는 455명 이었다. 세부적으로 보청기 이용자는 383명, 공급자는 41명, 전 문가는 31명이었다. 세 집단 모두에서 남성이 여성에 비해 많 았다. 이용자 집단은 연령이 증가하면서 많아지지만, 공급자 는 30 대, 전문가는 40 대가 가장 많았다. 거주지별로 분포를 살 펴보면, 이용자는 인천 및 경기가 가장 많았지만, 공급자와 전 문가는 서울이 가장 많았다(Table 1). 보청기 이용자의 청각장 애등급은 5급이 $31.6 \%$ 로 가장 많았고, 장애 판정 기간과 보청 기 이용 기간은 5년 이하가 많은 것으로 나타났다(Table 2).

\section{보청기 지원체계에 대한 인식}

보청기 지원체계에 대한 현황 및 개선방안에 대한 인식을 
대상자 유형별로 정리하였다(Table 3). 지원금액의 적정성 및 지원체계 만족도는 집단 간의 유의한 차이가 없었으나, 이외 의 모든 문항에서 집단 간의 유의한 차이를 보였다. 보청기 지원금액이 적정하지 않다고 응답한 대상자(이용자: $76.2 \%$, 공급자: $90.2 \%$, 전문가: $87.1 \%$ )가 가장 많았으며, 지원체계 만족도는 보통이라고 응답한 대상자(이용자: $42.0 \%$, 공급자: $56.1 \%$, 전문가: $45.2 \%$ )가 가장 많았다. 이용자의 $60.8 \%$ 가 보 청기 내구연한이 적정하지 않다고 응답하였지만 공급자의 $70.7 \%$ 와 전문가의 $64.5 \%$ 가 적정하다고 응답하였다. 보청기 지원 및 제공절차에 대한 정보의 접근성은 이용자의 $55.4 \%$ 와 전문가의 $64.5 \%$ 가 부적절하다고 응답하였지만, 공급자의 $53.7 \%$ 는 적절하다고 응답하였다. 청력검사비용 지원의 필요 성에 대해서 이용자의 $82.5 \%$ 와 공급자의 $95.1 \%$ 가 필요하다 고 하였지만, 전문가는 '필요하다'는 의견이 $48.4 \%$ 로 나타났 다. 보청기 종류별 차등지원은 이용자의 $63.5 \%$ 와 공급자의 $65.8 \%$ 가 필요하다고 하였지만, 전문가의 $61.3 \%$ 는 불필요하 다고 응답하였다. 장애등급별 차등지원에 대해서 이용자의 $84.3 \%$, 공급자의 $87.8 \%$, 전문가의 $64.5 \%$ 에서 필요하다고 하 였다. 수리비 지원 서비스는 이용자의 $59.5 \%$ 와 전문가의 $64.5 \%$ 가 필요하다고 하였지만, 공급자의 $51.2 \%$ 는 보통이라 고 응답하였다. 보청기 관련 지원체계의 보장성을 확대하기 위해 최우선으로 실시해야 할 항목으로 이용자의 $56.9 \%$ 와 전문가의 $80.6 \%$ 는 지원금 확대를, 공급자는 $68.3 \%$ 에서 대상 자 확대를 선택하였다.
지원체계에 대한 만족도와 독립변수 간의 상관관계를 보았 을 때, 지원체계 만족도에 가장 큰 영향을 미치는 변수는 관련 정보의 접근성이었으며, 통계적으로 유의한 양의 상관관계 $(\mathrm{r}=$ $0.522)$ 를 보였다 $(p<0.001)$. 독립변수 간의 상관관계는 -0.161 에서 0.299로 약하게 나타났다(Table 4). 보청기 지원체계 만 족도에 유의한 영향을 미치는 요인은 내구연한의 적정성, 관

Table 2. Characteristics of hearing aids user who responded to the questionnaire

\begin{tabular}{lrr}
\hline & $\begin{array}{r}\text { Persons } \\
(\mathrm{n}=383)\end{array}$ & $\%$ \\
\hline Disability Rating Scale for hearing loss & 52 & 13.6 \\
Grade 2 & 75 & 19.6 \\
Grade 3 & 73 & 19.1 \\
Grade 4-1 & 11 & 2.9 \\
Grade 4-2 & 121 & 31.6 \\
Grade 5 & 51 & 13.3 \\
Grade 6 & & \\
Duration after disability determination (yrs) & 137 & 35.8 \\
$<5$ & 104 & 27.2 \\
$5-10$ & 77 & 20.1 \\
$10-15$ & 65 & 17.0 \\
$>15$ & & \\
Duration of hearing aids use (yrs) & 118 & 30.8 \\
$<5$ & 95 & 24.8 \\
$5-10$ & 66 & 17.2 \\
$10-15$ & 104 & 27.2 \\
$>15$ & & \\
\hline
\end{tabular}

Table 1. Demographics and characteristics of the study population

\begin{tabular}{|c|c|c|c|c|c|c|c|c|c|}
\hline \multirow{2}{*}{ Variable } & \multicolumn{4}{|c|}{ User } & \multicolumn{2}{|c|}{ Supplier } & \multicolumn{2}{|c|}{ Specialist } & \multirow{2}{*}{ p-value } \\
\hline & Population & Sample & Respondent & $\%$ & $N$ & $\%$ & $N$ & $\%$ & \\
\hline \multicolumn{10}{|l|}{ Gender } \\
\hline Male & 5967 & 576 & 228 & 59.5 & 31 & 75.6 & 23 & 74.2 & 0.046 \\
\hline Female & 4861 & 424 & 155 & 40.5 & 10 & 24.4 & 8 & 25.8 & \\
\hline \multicolumn{10}{|l|}{ Age } \\
\hline$<30$ & 452 & 49 & 19 & 5 & 14 & 34.2 & 0 & - & $<0.0001$ \\
\hline $30-39$ & 263 & 28 & 20 & 5.2 & 19 & 46.3 & 6 & 19.4 & \\
\hline $40-49$ & 408 & 49 & 32 & 8.4 & 7 & 17.1 & 20 & 64.5 & \\
\hline $50-59$ & 1125 & 123 & 84 & 21.9 & 1 & 2.4 & 4 & 12.9 & \\
\hline$\geq 60$ & 8580 & 751 & 228 & 59.5 & 0 & - & 1 & 3.2 & \\
\hline \multicolumn{10}{|l|}{ Residence } \\
\hline Seoul & 1835 & 187 & 83 & 21.7 & 26 & 63.4 & 20 & 64.5 & $<0.0001$ \\
\hline Capital area & 2562 & 269 & 88 & 23 & 15 & 36.6 & 7 & 22.6 & \\
\hline Busan Kyungnam & 1387 & 145 & 56 & 14.6 & 0 & - & 0 & - & \\
\hline Daegu Kyungpook & 1409 & 124 & 50 & 13 & 0 & - & 0 & - & \\
\hline Gwangju Jeolla & 1510 & 112 & 47 & 12.3 & 0 & - & 1 & 3.2 & \\
\hline Daejeon Chungcheong & 1416 & 104 & 41 & 10.7 & 0 & - & 0 & - & \\
\hline Sejong, Gangwon, Jeju & 709 & 59 & 18 & 4.7 & 0 & - & 3 & 9.7 & \\
\hline Total & 10828 & 1000 & 383 & 100 & 41 & 100 & 31 & 100 & \\
\hline
\end{tabular}

Unit: persons, \% 
련 정보의 접근성, 보청기 종류별 차등지원의 필요성, 수리비 지원 필요성, 장애등급별 차등지원의 필요성이었다. 내구연 한이 적절하다고 응답한 대상자의 만족도는 부적절하다고 응답한 대상자에 비해 2.03배 높았고, 보청기 관련 정보 접근 성이 적절하다고 응답한 대상자의 만족도는 부적절하다고 응 답한 대상자에 비해 4.82배 높게 나타났다. 보청기 종류별 차 등지원이 필요하다고 응답한 대상자의 만족도는 불필요하다 고 응답한 대상자에 비해 1.98 배, 장애등급별 차등지원이 필
요하다고 응답한 대상자의 만족도는 불필요하다고 응답한 대 상자에 비해 1.91배 높았다(Table 5).

\section{고 찰}

2014년 국내 장애인 실태 조사에 따르면 청각장애인의 보청 기 사용률은 61.8\%(남자: 60.7\%, 여자: 63.0\%)이며, 2005년부 터 지속적으로 증가하고 있다고 한다. ${ }^{1)}$ 2009 2015년까지 7년

Table 3. Study population's understanding about hearing aids supporting system

\begin{tabular}{|c|c|c|c|c|c|c|c|}
\hline \multirow{2}{*}{ Variable } & \multicolumn{2}{|c|}{ User } & \multicolumn{2}{|c|}{ Supplier } & \multicolumn{2}{|c|}{ Specialist } & \multirow{2}{*}{ p-value } \\
\hline & $\mathrm{n}$ & $\%$ & $\mathrm{n}$ & $\%$ & $\mathrm{n}$ & $\%$ & \\
\hline Adequacy of financial supporting sum for hearing aids & & & & & & & 0.175 \\
\hline Adequate & 20 & 5.2 & 0 & - & 1 & 3.2 & \\
\hline Ordinary & 71 & 18.5 & 4 & 9.8 & 3 & 9.7 & \\
\hline Inadequate & 292 & 76.2 & 37 & 90.2 & 27 & 87.1 & \\
\hline Adequacy of accepted durability of hearing aids & & & & & & & $<0.0001^{*}$ \\
\hline Adequate & 52 & 13.6 & 29 & 70.7 & 20 & 64.5 & \\
\hline Ordinary & 98 & 25.6 & 6 & 14.6 & 8 & 25.8 & \\
\hline Inadequate & 233 & 60.8 & 6 & 14.6 & 3 & 9.7 & \\
\hline Accessibility to relevant information & & & & & & & $<0.0001^{*}$ \\
\hline Proper & 61 & 15.9 & 22 & 53.7 & 0 & - & \\
\hline Ordinary & 110 & 28.7 & 9 & 21.9 & 11 & 35.5 & \\
\hline Improper & 212 & 55.4 & 10 & 24.4 & 20 & 64.5 & \\
\hline Necessity of support hearing test charge & & & & & & & $<0.0001^{*}$ \\
\hline Necessary & 316 & 82.5 & 39 & 95.1 & 15 & 48.4 & \\
\hline Modest & 44 & 11.5 & 1 & 2.4 & 5 & 16.1 & \\
\hline Unnecessary & 23 & 6.0 & 1 & 2.4 & 11 & 35.5 & \\
\hline Necessity of graded financial support by type of hearing aids & & & & & & & $<0.0001^{*}$ \\
\hline Necessary & 243 & 63.5 & 27 & 65.8 & 8 & 25.8 & \\
\hline Modest & 66 & 17.2 & 5 & 12.2 & 4 & 12.9 & \\
\hline Unnecessary & 74 & 19.3 & 9 & 22.0 & 19 & 61.3 & \\
\hline Necessity of graded financial support by disability rating & & & & & & & $0.007^{*}$ \\
\hline Necessary & 323 & 84.3 & 36 & 87.8 & 20 & 64.5 & \\
\hline Modest & 36 & 9.4 & 4 & 9.8 & 4 & 12.9 & \\
\hline Unnecessary & 24 & 6.3 & 1 & 2.4 & 7 & 22.6 & \\
\hline Necessity of supporting service to repair & & & & & & & $<0.0001^{*}$ \\
\hline Necessary & 228 & 59.5 & 8 & 19.5 & 20 & 64.5 & \\
\hline Modest & 65 & 17.0 & 21 & 51.2 & 3 & 9.7 & \\
\hline Unnecessary & 90 & 23.5 & 12 & 29.3 & 8 & 25.8 & \\
\hline Satisfaction of hearing aids supporting system & & & & & & & 0.074 \\
\hline Satisfactory & 73 & 19.1 & 11 & 26.8 & 4 & 12.9 & \\
\hline Modest & 161 & 42.0 & 23 & 56.1 & 14 & 45.2 & \\
\hline Unsatisfactory & 149 & 38.9 & 7 & 17.1 & 13 & 41.9 & \\
\hline Desired expanding coverage & & & & & & & $<0.0001^{*}$ \\
\hline Expansion of eligibility & 22 & 5.7 & 28 & 68.3 & 4 & 12.9 & \\
\hline Expansion of financial supporting sum & 218 & 56.9 & 8 & 19.5 & 25 & 80.6 & \\
\hline Expansion of relevant service & 143 & 37.3 & 5 & 12.2 & 2 & 6.5 & \\
\hline Total & 383 & 100 & 41 & 100 & 31 & 100 & \\
\hline
\end{tabular}

Unit: persons, \%. *significant $p$-values 
간 국민건강보험공단을 통해 보청기 급여를 받은 청각장애인 은 114429명으로, 2015년 12월 현재 250334명이 등록된 청각
장애인의 $45.7 \%$ 에 해당한다. 통계 결과치가 공개된 다른 나라 청각장애인의 보청기 사용률은 2012년 일본은 $14.1 \%, 2009$ 년

Table 4. The correlation between independent variable to satisfaction level of hearing aid supporting system

\begin{tabular}{|c|c|c|c|c|c|c|c|c|}
\hline Variable & $\begin{array}{l}\text { Satisfaction } \\
\text { level of } \\
\text { supporting } \\
\text { system }\end{array}$ & $\begin{array}{l}\text { Adequacy } \\
\text { of financial } \\
\text { supporting } \\
\text { sum for } \\
\text { hearing aids }\end{array}$ & $\begin{array}{l}\text { Adequacy } \\
\text { of accepted } \\
\text { durability of } \\
\text { hearing aids }\end{array}$ & $\begin{array}{l}\text { Accessibility } \\
\text { to relevant } \\
\text { information }\end{array}$ & $\begin{array}{c}\text { Necessity } \\
\text { of support } \\
\text { hearing } \\
\text { test } \\
\text { charge }\end{array}$ & $\begin{array}{c}\text { Necessity } \\
\text { of graded } \\
\text { financial } \\
\text { support } \\
\text { by type of } \\
\text { hearing aids }\end{array}$ & $\begin{array}{l}\text { Necessity } \\
\text { of graded } \\
\text { financial } \\
\text { support by } \\
\text { disability } \\
\text { rating }\end{array}$ & $\begin{array}{l}\text { Necessity } \\
\text { of } \\
\text { supporting } \\
\text { service to } \\
\text { repair }\end{array}$ \\
\hline \multirow{2}{*}{$\begin{array}{l}\text { Satisfaction level } \\
\text { of supporting } \\
\text { system }\end{array}$} & \multirow[t]{4}{*}{1} & 0.220 & 0.287 & 0.522 & -0.095 & 0.126 & -0.111 & 0.049 \\
\hline & & $<0.0001^{*}$ & $<0.0001^{*}$ & $<0.0001^{*}$ & $0.043^{*}$ & $0.007^{*}$ & $0.017^{*}$ & 0.300 \\
\hline \multirow{2}{*}{$\begin{array}{l}\text { Adequacy } \\
\text { of financial } \\
\text { supporting sum } \\
\text { for hearing aids }\end{array}$} & & 1 & 0.160 & 0.250 & -0.161 & -0.048 & -0.109 & 0.012 \\
\hline & & & $0.001 *$ & $<0.0001^{*}$ & $0.001 *$ & 0.307 & $0.021^{*}$ & 0.806 \\
\hline \multirow{2}{*}{$\begin{array}{l}\text { Adequacy of } \\
\text { accepted } \\
\text { durability of } \\
\text { hearing aids }\end{array}$} & & & 1 & 0.299 & -0.091 & 0.012 & -0.140 & -0.016 \\
\hline & & & & $<0.0001^{*}$ & 0.052 & 0.791 & $0.003^{*}$ & 0.730 \\
\hline \multirow{2}{*}{$\begin{array}{l}\text { Accessibility to } \\
\text { relevant } \\
\text { information }\end{array}$} & & & & 1 & -0.017 & 0.086 & -0.035 & -0.054 \\
\hline & & & & & 0.722 & 0.066 & 0.450 & 0.251 \\
\hline \multirow{2}{*}{$\begin{array}{l}\text { Necessity of } \\
\text { support hearing } \\
\text { test charge }\end{array}$} & & & & & 1 & 0.130 & 0.264 & 0.009 \\
\hline & & & & & & $0.005^{*}$ & $<0.0001^{*}$ & 0.845 \\
\hline \multirow{2}{*}{$\begin{array}{l}\text { Necessity of graded } \\
\text { financial support } \\
\text { by type of hearing } \\
\text { aids }\end{array}$} & & & & & & 1 & 0.143 & 0.115 \\
\hline & & & & & & & $0.002^{*}$ & $0.014^{*}$ \\
\hline \multirow{2}{*}{$\begin{array}{l}\text { Necessity of graded } \\
\text { financial support } \\
\text { by disability rating }\end{array}$} & & & & & & & 1 & 0.086 \\
\hline & & & & & & & & 0.066 \\
\hline $\begin{array}{l}\text { Necessity of } \\
\text { supporting } \\
\text { service to repair }\end{array}$ & & & & & & & & 1 \\
\hline
\end{tabular}

Table 5. Factors affecting satisfaction level of hearing aid supporting system

\begin{tabular}{llc}
\hline \multicolumn{1}{c}{ Variable } & OR & $95 \% \mathrm{Cl}$ \\
\hline Type of population & 1.66 & $0.42-6.50$ \\
Supplier (ref: user) & 1.30 & $0.32-5.27$ \\
Specialist (ref: user) & 1.28 & $0.70-2.34$ \\
Understanding present condition of supporting system & $2.03^{*}$ & $1.14-3.60$ \\
Adequacy of financial supporting sum for hearing aids (ref: inadequate) & $4.82^{*}$ & $2.65-8.78$ \\
Adequacy of accepted durability of hearing aids (ref: inadequate) & 1.04 & $0.50-2.16$ \\
Accessibility to relevant information (ref: improper) & $1.98^{*}$ & $1.10-3.59$ \\
Improvement plan of supporting system & $1.91^{*}$ & $1.07-3.42$ \\
Necessity of support hearing test charge (ref: unnecessary) & $0.35^{*}$ & $0.18-0.70$ \\
Necessity of graded financial support by type of hearing aids (ref: unnecessary) & & \\
Necessity of graded financial support by disability rating (ref: unnecessary) & 0.92 & $0.35-2.38$ \\
Necessity of supporting service to repair (ref: unnecessary) & 1.23 & $0.45-3.33$ \\
Desired expanding coverage & & \\
Expansion of financial supporting sum (ref: expansion of eligibility) & & \\
Expansion of relevant service (ref: expansion of eligibility) & & \\
\hline
\end{tabular}

*significant $p$-values. OR: odd ratio, Cl: confidence interval 
Table 6. The number and sum of hearing aid through national supporting system in recent years (provided by NHIS)

\begin{tabular}{|c|c|c|c|c|c|c|c|c|c|c|c|c|c|c|c|}
\hline \multicolumn{2}{|c|}{2009} & \multicolumn{2}{|c|}{2010} & \multicolumn{2}{|c|}{2011} & \multicolumn{2}{|c|}{2012} & \multicolumn{2}{|c|}{2013} & \multicolumn{2}{|c|}{2014} & \multicolumn{2}{|c|}{2015} & \multicolumn{2}{|c|}{2016} \\
\hline$n$ & Sum & $n$ & Sum & $n$ & Sum & $n$ & Sum & $n$ & Sum & $n$ & Sum & $n$ & Sum & $n$ & Sum \\
\hline 23323 & 6327 & 20176 & 5478 & 15866 & 4308 & 13709 & 3716 & 15368 & 4174 & 15447 & 4202 & 20540 & 12648 & 58235 & 67094 \\
\hline
\end{tabular}

독일은 31.8\%, 2008년 미국은 24.6\%로 우리나라보다 낮게 알려져 있다. ${ }^{2)}$ 이는 나라마다 청각장애의 기준이 다른데 외국 에서는 일반적으로 $30 \mathrm{~dB}$ 이상의 경도 난청에서도 보청기의 사용이 권고되어 일본, 독일, 미국 모두에서 전체 인구의 $10 \%$ 이상을 청각장애 환자로 분류하였기 때문으로 보인다. 2014년 장애인 실태 조사에서 청각장애인이 인구 1000명당 6.43명으 로 파악한 우리나라와 직접적으로 보청기 보급률을 비교하 기에는 무리가 있다. 실제 우리나라 국민건강영양조사(20102012 Korea National Health and Nutrition Examination Survey) 자료를 분석한 연구를 보면 50대 연령의 평균 청력은 고 주파 영역에서 정상 이하로 떨어지기 시작하여 60대 연령의 평 균 청력은 경도 난청 수준에 들어가게 된다.) 또한 60대 이상 의 연령에서 경도 난청 $(>25 \mathrm{~dB})$ 이상인 경우가 $69.7 \%$, 중등도 이상의 난청을 가진 비율은 $36.8 \%$ 로 보고되었다. ${ }^{5)}$ 기존의 국 내에서 수행된 보청기 이용률에 관한 연구 및 조사에서 연구 대상자 특성에 따라 보청기 이용률이 상이하다. 국민건강영양 조사를 활용한 보청기 이용 현황에 관한 연구에서 40 세 이상 양측 모두 $40 \mathrm{~dB}$ 이상의 순음청력 역치 결과를 보인 사람들을 대상으로 한 보청기 구입과 이용률은 각각 $17.4 \%$ 와 $12.6 \%$ 였 다.) 2014 년도에 보청기를 구매한 청각장애인을 대상으로 설 문조사를 실시한 본 연구에서 보청기를 자주 이용한다는 청각 장애인은 전체 청각장애인의 $92.2 \%$ 였다.

청각장애인은 의사소통수단으로써 $80 \%$ 이상은 '말'을 사 용하는 것으로 알려져 있는데, 양측 $60 \mathrm{~dB}$ 이상의 중등고도 난청을 가지고 일상적인 생활과 사회 활동을 유지하기는 힘 들다. 청력 기능 저하 및 장애는 일상생활 활동뿐만 아니라 우 울 등의 심리상태와 삶의 질에 부정적인 영향을 미친다. ${ }^{7-9)}$ 청각장애와 낙상과의 관련성을 확인한 연구에서는 청각장애 가 낙상의 위험을 최소 1.4 배에서 최대 1.6 배까지 높인다고 하 였다. ${ }^{10)}$ 근로자 748 명을 대상으로 청력이 병가 및 작업 생산성 에 미친 영향을 확인한 결과 청력이 나쁜 근로자가 업무 후 회 복의 이유로 청력이 좋은 근로자에 비해 4개월 동안 5 일 이상 의 병가를 더 내며, 청력이 작업 생산성에 유의미한 영향을 미 친다고 보고하였다. ${ }^{11)} \mathrm{Acar}$ 등 ${ }^{12)}$ 은 65 세 이상의 청각장애인에 게서 보청기 사용 이후에 우울 증상이 줄어드는 것과 인지기 능이 향상하는 것을 확인하였다. 우울증 진단을 받지 않은 65 세 이상 노인을 대상으로 청각 손실이 우울증에 미친 영향을 확인한 Saito 등ํ)은 청력 손실이 우울증 발생을 2.45 배 높인
다고 보고하였다.

보청기 등의 보장구를 이용하고 약간의 도움만 있으면 청각 장애인의 삶의 질을 향상시킬 수 있으며, 사회적 비용을 줄일 수 있다. 외국의 많은 연구에서는 청각장애인을 대상으로 삶 의 질 개선에 관한 보청기의 효과를 입증하였다. Mulrow 등 ${ }^{14)}$ 은 보청기를 사용하는 192명의 노인을 대상으로 4가지 삶의 질 지표를 측정하였으며, 보청기 사용 이후 삶의 질이 전반적 으로 호전되었다고 보고하였다. 또한, 보청기와 더불어 청각 훈련/재활 및 보조기구를 병행할 경우에 보청기를 사용하는 청각장애인의 삶의 질이 향상되었다. 정상인과 청각장애인을 대상으로 단음절 단어를 9 14일간 청각 훈련을 시킨 Burk 등 ${ }^{15)}$ 은 청각 훈련을 통해 청각장애인의 단어인지도가 향상된 것을 확인하였다. 보청기를 처음 사용하는 청각장애인과 기존 에 사용하고 있는 청각장애인을 대상으로 digital versatile disc 를 활용한 청각 훈련을 시킨 Olson 등 ${ }^{16}$ 은 실험집단의 청각능 력이 비교집단에 비해 향상된다는 것을 확인하였다. 모바일 기구를 활용한 청각훈련 프로그램의 효과를 확인하기 위한 연구에서는 보청기를 사용하는 청각장애인이 보조기구를 병 행하여 단어인지도가 유의하게 향상된 것을 확인하였다. ${ }^{17)}$

본 연구에서는 2014년도에 보청기를 구매한 이용자(청각장 애인), 보청기 판매와 영업을 담당하는 공급자, 그리고 이비인 후과 전문의를 대상으로 설문조사를 진행하였으며, 최종분 석에 활용된 대상자는 455 명이었다. 이 연구는 보청기 이해집 단의 보청기 지원체계 현황 및 개선방안에 대한 인식을 파악 하고 보청기 지원체계 만족도에 미치는 영향요인 및 크기를 확 인하였다.

성, 연령, 거주지, 대상자 유형 등의 인구사회학적 요인은 보 청기 지원체계 만족도에 영향을 미치지 않았다. 보청기 지원체 계 만족도에 유의한 영향을 미치는 요인은 내구연한의 적정 성, 관련 정보 접근성, 보청기 종류별 차등지원의 필요성, 수 리비 지원의 필요성, 장애등급별 차등지원의 필요성이었다. 보청기 내구연한 및 관련 정보에 대한 접근성이 적절하다고 판단하는 대상자는 보청기 지원체계에 만족도가 높은 것으로 나타났다. 보청기 지급과 관련된 정보의 접근성이 보청기 지원 체계의 만족도에 가장 큰 영향을 주는 것으로 나타났는데, 이 는 지금처럼 지원금액만을 대폭 상향하는 것보다 만족도 개 선을 위해서는 관련 정보에 손쉽게 접근할 수 있는 시스템을 구축하는 것이 필요할 것으로 보인다. 보청기 종류별 차등지 
원 및 장애등급별 차등지원이 필요하다는 대상자는 오히려 보청기 지원체계에 대한 만족도가 높았다. 현재 지원체계에도 만족하지만 차등지원의 필요성이 있다고 보는 의견이지만 보 청기 종류별, 가격별로 지원금을 차등 지급할 경우에 경제적으 로 여유가 있는 청각장애인이 고가의 채널을 선택하여 더 많 은 혜택이 돌아갈 수 있기 때문에 보청기의 형태 및 기능에 따 른 차등 지급하는 것은 문제가 있다고 보인다. 또한 보청기에 대한 기대 및 만족도는 장애등급에 관계없이 개인에 따른 차 이에서 발생하기 때문에 장애등급에 따라 지원금을 차등 지 급하는 것은 쉽지 않다.

사후 관리 서비스에 해당하는 수리비 지원이 필요하다는 응 답자의 만족도는 불필요하다는 응답자보다 낮았다. 특히 보 청기 수리비 지원이 필요하다고 생각하는 청각장애인은 보청 기 지원체계에 불만족이라는 응답이 많았는데, 이는 보청기 구입 후 사후 관리에 대한 관심이 공급자나 전문가는 감소하 지만 이용자는 보청기 기능에 대한 불만으로 인해 나타난 것 으로 보인다. 청각장애인이 보청기를 효과적으로 사용하기 위해 보청기적합의 확인, 청능 훈련 등의 지원이 필요하지만 이에 대한 지원 및 관리가 부족한 실정이다. 청각장애인이 구 입한 보청기가 제대로 사용되도록 체계적인 사후 관리 시스템 이 마련되어 정기적으로 보청기적합 서비스를 지원하는 방안 을 모색할 필요가 있다.

보청기 지원체계 보장성 강화를 위한 최우선 항목으로 인식 하는 설문에서 보청기 이용자와 전문가는 지원금 확대를 선 택하였지만, 공급자는 지원대상 확대를 선택하였다. 보청기 이용자와 전문가는 보청기 소비자가를 감안했을 때 당시 지원 금(34만 원)이 낮다고 판단하고 있었다. 이용자의 $76.2 \%$ 와 전 문가의 $87.1 \%$ 는 보청기 지원금액이 적당하지 않다고 응답하 였다. 공급자의 $90.2 \%$ 가 보청기 지원금액이 적당하지 않다고 응답하였지만, 공급자의 $68.3 \%$ 가 보청기 지원체계 보장성 강 화를 위한 최우선 과제로 지원대상 확대를 선택하였다. 이는 설문에 참여한 보청기 이용자 모두 청각장애 판정을 받은 인 원이므로 지원대상의 확대 필요성을 인식하기 어렵고 보청기 전문가는 실제 장애 판정을 위한 검사 비용보다 적은 지원금 액이 문제가 있다고 판단한 것으로 보인다. 보청기 공급자 입 장에서는 보청기의 실제 가격과 지원금 차이가 너무 크다고 판단하지만 청각장애 판정을 받지 못한 난청 환자의 보청기 지원이 필요하다고 보았고 여기에는 개인이나 기업의 경제 논 리가 반영된 것으로 보인다. 보청기 가격은 제조사마다 차이 가 있으나 평균적으로 2 채널 보청기는 약 150 만 원대, 4채널 보청기는 약 200만 원대, 6채널 보청기는 약 300만 원대, 8 채 널 보청기는 약 400 만 원대, 10 채널 이상의 보청기는 약 500 만 원 이상으로 판매되고 있다. ${ }^{2)}$ 2014 2018년 건강보험 중기
보장성 강화 계획에 따라 2015년 11월 15일자로 국민건강보험 법 시행 규칙이 일부 개정되어 청각장애인의 급여 품목인 보청 기의 기준액이 131 만 원으로 상향 조정되었다. 그리고 15 세 이 하의 경우 양측 보청기 급여가 가능하도록 고시되어 소아 청각 장애인의 양이청을 위한 보청기 사용에는 큰 도움이 되었다. 하지만 순음청력검사 및 어음청력검사가 어려운 영유아의 경 우 양측 급여 대상자 세부 인정 기준을 만족하기 어려운 측면 이 있고, 경제적 여건이 어려운 50 60 dB 정도의 양측 감각신 경성 난청을 가진 고령 환자의 경우 보청기가 필요하지만 장 애 판정을 받지 못해 급여 대상에서 제외되는 문제 등이 생겨 이를 해결할 제도적 보완도 필요할 것으로 보인다. 미국의 연 구에 따르면 노화 관련 질환 중 대표적인 난청 질환은 환자의 독립성, 생산성, 삶의 질 저하에 심각한 영향을 미치며 60세 이상의 $40 \%, 70$ 세 이상의 $60 \%, 80$ 세 이상의 연령에서는 $80 \%$ 에 이를 정도로 많은 유병률을 보이는 것으로 나타났다. ${ }^{18)}$ 특 히 외이나 중이 질환 등의 과거력이 없는 80 대 이상에서도 저 주파 영역의 평균 청력이 $40 \mathrm{~dB}$ 이상, 고주파 영역은 $60 \mathrm{~dB}$ 이 상의 역치를 보이게 되어 보청기 등의 도움 없이는 일상생활에 어려움이 발생된다. 또한 적절한 치료가 되지 않은 난청은 노 인에서 타인과의 관계가 소원해져 사회적 고립이나 노동력의 상실 등을 유발시키고 우울증, 치매, 인지 기능 저하 등을 가져 오는 것으로 알려져 있다. ${ }^{19)}$ 우리나라도 고령 사회를 넘어 초 고령 사회로 빠르게 넘어가는 시점에서 노화에 따른 난청 문 제를 청각장애 판정 대상자의 틀에만 가두지 말고 사회적 기 회 비용 측면으로 고려하여 정책적인 노력이 필요할 것으로 보 인다.

지난 5년간(2009 2013년) 장애인 보장구 급여현황을 살펴 보면, 2009년도 343억 원, 2010년도 289억 원, 2011년도 272 억 원, 2012년도 274억 원, 2013년도 323억 원으로 국민건강 보험공단에서 장애인에게 매년 약 300 억 원을 지원하고 있다. 5 년간 청각장애인에게 지급된 금액은 최소 37 억 원에서 최대 63억 원으로 전체 지원금액의 12.9 19.0\%이다. 2015년 11월 15 일 지원금이 131만 원으로 상향되면서 2015년 보청기 급여 건 수는 예년과 비슷한 수준이었으나 소요된 재정은 126 억 원으 로 급격히 상승하였다. 또한 2016년에는 급여 건수가 58235건 으로 3 배 정도 많아졌고, 공단 부담액은 670 억 원으로 예년보 다 10배 이상 수직 상승한 결과를 보였다(Table 6). 국민건강 보험공단에서 전체 장애인 보장구에 관련된 향후 5 년간 연평 균 공단 부담액 추정치를 387 억 원에서 477 억 원으로 예상한 것을 감안할 때 보청기 급여비에만 전체 장애인 보장구 예산 의 2 배를 사용한 셈이다. ${ }^{20)}$ 제도의 지속적 확대를 위해서는 보 청기가 도움이 되지 않거나 인공중이, 인공 와우 시술이 필요 한 청각장애 환자에 대해 보청기 급여비가 지급되지 않도록 이 
비인후과 의사의 노력도 필요할 것으로 보인다.

2015년 국민건강보험법 시행 규칙 개정에 따라 지원금의 확 대와 소아 양측 급여와 같은 지원대상의 일부 확대가 이루어 졌다. 하지만 보청기 관련 지원체계의 보장성 확대를 위해서 는 보청기 구입 후 지속적인 활용을 위한 사후 관리 서비스도 필수적이다. 즉 초기 적합성 검증과 변화하는 환자의 청력에 맞추어 조절할 수 있도록 규칙적인 보청기 적합 서비스를 제공 할 수 있는 원가 분석을 통한 적절한 수가 산정이 필요하고 보 청기 급여 비용에 포함하는 것이 적절할 것으로 보인다. 또한 보청기를 통한 장애인의 청각재활이 제대로 이루어지는지 평 가하여 내구연한 이후 다시 보청기 급여를 청구할 때 참고 자 료로 쓸 수 있도록 해야 할 것이다. 보청기를 적절히 사용하는 청각장애인은 일상생활 능력뿐만 아니라 삶의 질도 향상된 다. ${ }^{14)}$ 선행연구에서 청각장애인을 대상으로 보조기구 사용 및 청각재활이 언어 인지능력을 향상시키는 것으로 알려져 향후 청각장애인에게 청각재활 등의 관련 서비스를 지원해 주는 방안도 고려해 볼 수 있다.

건강보험제도에 대한 대중의 만족도는 효율성 개선 및 의 료비 지출 확대 등의 경제적 성과와 관련이 없다고 알려져 있 다. ${ }^{21,22)}$ 제도 만족도를 결정하는 주요한 요인은 제도에 대한 인식 및 태도이기 때문에, 올바른 보청기 이용 및 제도 만족도 제고를 위해 건강보험공단에서는 보청기 지원체계에 대한 홍 보 전략 마련도 필요할 것이다. 실제로 기존 보건의료정책에 대하여 잘못하고 있다고 생각하거나 복지인식이 뚜렷하지 않 은 경우에 건강보험에 대한 만족도는 떨어지고, 국민들은 건강 보험의 역할을 축소하는 것(민간보험 활성화)에 동의한 것으 로 나타났다. ${ }^{23)}$

본 연구의 몇 가지 제한점이 있다. 첫째, 표본의 대표성이다. 보청기를 이용하는 청각장애인을 대상으로 설문을 진행하였 으나, 여러 가지 이유로 보청기를 이용하지 않는 청각장애인 을 대상으로 한 현황조사가 병행되지 못하였기 때문에 전체 청각장애인의 의견이 반영되었다고 보기 힘들다. 또한, 설문 에 참여한 공급자와 전문가가 모집단을 대표한다고 보기 힘 들다. 공급자의 절반 이상이 근무연수가 5년 미만이었으며, 전문가의 절반 이상이 종합병원에 근무하고 있었다. 하지만 제한된 환경에서 이해당사자 간의 보청기 지원체계에 대한 인식 및 만족도 차이를 확인한 것은 의미 있는 시도라고 할 수 있다. 둘째, 연구에서 사용된 종속변수와 독립변수가 응 답자의 주관적인 인식을 측정하였기 때문에 주의깊은 해석 이 필요하다. 자기보고에 의해 작성되었기 때문에 과소 또는 과대 보고될 가능성이 존재하지만 설문조사가 우편조사나 이메일조사로 진행되었기 때문에 이러한 문제점이 최소화되 었다고 판단된다. 셋째, Likert 5척도로 이루어진 문항에서 중립(neutral)이라고 응답한 경우를 어떻게 처리하느냐에 관한 문제이다. 보통은 적절성이나 필요성에 대한 표현을 유보한 것 으로 볼 수 있다. '보통’이라는 답변을 '적절'과 ‘필요’에 혹은 '부 적절'과 '불필요'에 포함하느냐에 따라 결과 해석이 달라질 수 있다.

본 연구에서는 보청기와 관련된 이해당사자인 이용자, 공급 자, 전문가를 대상으로 보청기 지원체계 현황 및 개선방안에 대한 인식을 파악하고 보청기 지원체계 만족도에 어떠한 영 향을 미치는지 살펴보고 그 크기를 파악하고자 하였다. 과거 에도 청각장애의 영향 및 보청기의 효과에 관한 연구는 많았 으나, 보청기 지원체계에 대한 인식 및 만족도를 확인한 연구 가 부족하다는 점에서 이 연구의 의의가 있다고 할 수 있다.

\section{REFERENCES}

1) Kim SH, Lee YH, Hwang JH, Oh MA, Lee MK, Lee NH, et al. Survey of the living conditions of disabled people 2014 [cited 2017 January 15]. Available from: https://www.kihasa.re.kr/web/publication/research/ view.do?division $=002 \&$ ano $=1918 \&$ menuId $=45 \&$ tid $=71 \&$ bid $=12$.

2) Lee JS, Kim JW, Park SM, Kim KS. Hearing aid [cited 2017 January 15]. Available from: https://www.khidi.or.kr/board/view?linkId=13 9574\&menuId=MENU00368.

3) Park CY, Suh NK, Lee AK. A research design to investigate the perception and satisfaction on National Health Insurance. Health Soc Sci 2007;22(12):97-126.

4) Kim CY, Jeong SW, Seo JY, Lee YJ, Park SC, Choi HS. The prevalence and risk factors of tinnitus in Korean adolescents. Korean J Otorhinolaryngol-Head Neck Surg 2015;58(1):12-8.

5) Hong JW, Jeon JH, Ku CR, Noh JH, Yoo HJ, Kim DJ. The prevalence and factors associated with hearing impairment in the Korean adults: the 2010-2012 Korea National Health and Nutrition Examination Survey (observational study). Medicine (Baltimore) 2015;94(10):e611.

6) Moon IJ, Baek SY, Cho YS. Hearing aid use and associated factors in South Korea. Medicine (Baltimore) 2015;94(42):e1580.

7) Lin FR, Yaffe K, Xia J, Xue QL, Harris TB, Purchase-Helzner E, et al. Hearing loss and cognitive decline in older adults. JAMA Intern Med 2013;173(4):293-9.

8) Lemke U, Scherpiet S. Oral communication in individuals with hearing impairment-considerations regarding attentional, cognitive and social resources. Front Psychol 2015;6:998.

9) Pronk M, Deeg DJ, Smits C, Twisk JW, van Tilburg TG, Festen JM, et al. Hearing loss in older persons: does the rate of decline affect psychosocial health? J Aging Health 2014;26(5):703-23.

10) Lin FR. Hearing loss and cognition among older adults in the United States. J Gerontol A Biol Sci Med Sci 2011;66(10):1131-6.

11) Nachtegaal J, Festen JM, Kramer SE. Hearing ability in working life and its relationship with sick leave and self-reported work productivity. Ear Hear 2012;33(1):94-103.

12) Acar B, Yurekli MF, Babademez MA, Karabulut H, Karasen RM. Effects of hearing aids on cognitive functions and depressive signs in elderly people. Arch Gerontol Geriatr 2011;52(3):250-2.

13) Saito H, Nishiwaki Y, Michikawa T, Kikuchi Y, Mizutari K, Takebayashi T, et al. Hearing handicap predicts the development of depressive symptoms after 3 years in older community-dwelling Japanese. J Am Geriatr Soc 2010;58(1):93-7.

14) Mulrow CD, Tuley MR, Aguilar C. Sustained benefits of hearing aids. J Speech Hear Res 1992;35(6):1402-5.

15) Burk MH, Humes LE, Amos NE, Strauser LE. Effect of training on word-recognition performance in noise for young normal-hearing 
and older hearing-impaired listeners. Ear Hear 2006;27(3):263-78.

16) Olson AD, Preminger JE, Shinn JB. The effect of LACE DVD training in new and experienced hearing aid users. J Am Acad Audiol 2013;24(3):214-30.

17) Yu J, Jeon H, Song C, Han W. Speech perception enhancement in elderly hearing aid users using an auditory training program for mobile devices. Geriatr Gerontol Int 2017;17(1):61-8.

18) Lin FR, Niparko JK, Ferrucci L. Hearing loss prevalence in the United States. Arch Intern Med 2011;171(20):1851-2.

19) Cassel C, Penhoet E, Saunders R. Policy solutions for better hearing. JAMA 2016;315(6):553-4.

20) Kong YC, Cho KW, Kim DH. A study on reasonable prices estimation method of assisting devices for the disabled [cited 2017 January 15]. Available from: http://ib.nhis.or.kr/search/detail/CATXBZ000000004765.

21) Blendon RJ, Benson JM. Americans' views on health policy: a fiftyyear historical perspective. Health Aff (Millwood) 2001;20(2):33-46.

22) Adang EM, Borm GF. Is there an association between economic performance and public satisfaction in health care? Eur J Health Econ 2007;8(3):279-85.

23) Heo Si, Shin HS, Kang MA, Kim TI, Kim JB. Improving methods in optimal coverage of health insurance [cited 2017 January 15]. Available from: http://repository.kihasa.re.kr:8080/bitstream/201002/478/2/\% EC\%97\%B0\%EA\%B5\%AC-07-05.pdf. 